\title{
Does millennials have an investment interest? theory of planned behaviour perspective
}

\author{
Noni Setyorini ${ }^{1}$ and Ika Indriasari ${ }^{1}$ \\ ${ }^{1}$ Management Department, Economics and Business Faculty, Universitas PGRI Semarang
}

\begin{abstract}
This study aims to determine the effect of attitudes, subjective norms, and perceived behavioral control of interest in investing. This research use theory of planned behavior to explain how behavior is formed through attitudes, subjective norms, and perceived behavioral control in taking investment decision. This research uses online survey data collection methods. Sampling uses the convenient sampling method. Data (questionnaire) which can be used as many as 100 data and using multiple regression analysis as the test tool. The results showed that the attitude variable has not a significant effect towards investing interest in the capital market, while subjective and perceived norms behavioral control has influenced investment interest in the capital market. Based on the research findings, it is advisable to use persuasion that emphasizes the involvement of those closest to potential investors. In addition, seminars organized by IDX and the government will greatly help increase investor knowledge, thereby increasing one's investment power control.
\end{abstract}

\section{INTRODUCTION}

The rapid development of technology has caused the emergence of new industries (Menzel \& Fornahl, 2010) and one of the most fastest growing industries is financial technology or fintech, which combines financial access with technological and digital assistance. According to the data from Boston Consulting Group (BCG), the MAC (middle-class and affluent customers) population in Indonesia in 2020 is projected to reach 141 million people or 64 percent of Indonesia's current population.

Ayuningtyas et al. (2010) considered that urban-middle-class millennials are early adopters of the latest technology. Urban middle class millennials have already been very familiar with shopping either through social media (Facebook, Instagram, WhatsApp) commonly known as social commerce, or through e-commerce platforms of which the payment systems are far more complete - particularly because these platforms are supported by financial technology (fintech). The large population of users who have shopping transactions through social media and e-commerce in Indonesia, which is projected to reach 130 billion US dollars in 2020, has driven many parties to invest trillions of rupiah to facilitate their shopping experiences, both offline and online (Morgan,2019).

An increase in cashless transactions has made it easier for millennials to spend their money since they do not feel like physically spending money (Runnemark, Hedman \& Xiao, 2015). In fact, it is necessary to balance the innovations of fintech services and products that provide comfort and convenience for millennials with responsibility (King \& Nesbitt, 2019). It is appropriate to expect Fintech to be a catalyst for good financial behavior. A survey from Manulife Investor Sentiment Index showed that 60 percent of its respondents said that they wanted to have better control of their spending, but they did not have adequate tools, while 53 percent of the respondents said that they regretted of not having early financial plans.

Data from the Indonesia Stock Exchange (2019) shows that the largest number of investors comes from the age group 41-100. Nevertheless, only investors from the millennial generation experienced positive growth. As of September 2019, the number of investors in the 41-100 age group was 354 thousand, a decrease of $22.88 \%$ from 2016 which reached 459 thousand. While for millennial generation, the highest increase came from the age group of 18-25 years. Its 
growth recorded reached $181.01 \%$ from 79 thousand in 2016 to 222 thousand investors. While the increase of the 26-30 years age group was $57.73 \%$ and $31-40$ years old was $57.73 \%$. As for when viewed based on the number, investors with the age group 31-40 lead among other millennials, namely as many as 251 thousand people.

Financial behavior is an important thing for urban middle-class millennials because they have high buying power. This behavior includes millennials' knowledge about financial products, types of financial products, and behavior in making financial transactions. Millennials make use of financial products not only for buying process but also for investments. In fact, investment is an important thing for financial planning to secure future financial needs.

Research disclosed by Triwijayati \& Koesworo (2006) found that someone who has an interest in investing will likely take actions that can achieve their desire to invest, such as attending investment seminars and training, attending study groups, accepting investment offers, and ultimately make an investment. In addition, being an investor while still in the study environment will greatly benefit, including (1) saving to guarantee the future, (2) saving for learning and profit (Lechter \& Kiyosaki, 2001)

To understand millennials' behavior in making investment can be done using psychological theories. One theory which is widely used is Theory of Reasoned Action (TRA) proposed by Fishbein and Ajzen (1975). This theory was then further developed by Ajzen (1985) into Theory of Planned Behavior (TPB), aimed to more specifically predict individual behavior (Ramdhani, 2011). The Theory of Planned Behavior comprises three main components, namely attitudes, subjective norms, and perceived behavioral control.

Intentions to perform behaviors of different kinds can be predicted with high accuracy from attitudes toward the behavior, subjective norms, and perceived behavioral control; and these intentions, together with perceptions of behavioral control, account for considerable variance in actual behavior. Attitudes, subjective norms, and perceived behavioral control are shown to be related to appropriate sets of salient behavioral, normative, and control beliefs about the behavior (Ajzen, 1991). These three components can be used to assess millennials' intention to make investments. This is because intention to use is manifestation of someone's intention to do something.

\section{LITERATURE REVIEW AND HYPOTHESES DEVELOPMENT}

\section{Theory of planned behaviour}

This theory, which was first known as theory of reasoned action (TRA), was developed in 1967, after which the theory was revised and elaborated by Icek Ajzen and Martin Fishbein. Starting in 1980, the theory was used to study human behaviors and to develop more meaningful interventions. In 1988 , several things were added to the existing reasoned action model, and the theory was then called Theory of Planned Behavior (TPB), to address the issues which remained unsolved by Ajzen and Fishbein through their studies using TRA (Achmat, 2010).

\section{Attitude}

Ajzen (2005) mentions that attitudes towards behavior are determined by the beliefs in certain consequences of a behavior or commonly known as behavioral beliefs. Beliefs are related to individuals' subjective assessment of the world that surrounds them, individuals' understanding of themselves and their environment, by linking certain behaviors with various possible disadvantages or advantages that they might get from doing or not doing such behaviors (Ramdhani, 2011).

\section{Subjective norm}

Subjective norms are individuals' perceptions of the expectations of people who are influential in their lives (significant others) regarding whether certain behaviors are done or not done. Such perceptions are subjective, so this dimension is called as subjective norms. Similar with attitudes towards behavior, subjective norms are also affected by beliefs. The difference is that, attitudes towards behavior are a function of individuals' beliefs in certain behaviors to perform (behavioral belief), while subjective norms are a function of individuals' beliefs obtained from other people's opinions about the attitudes related to individuals (normative belief) (Ramdhani, 2011). 
In the daily life, the relationships established by each individual can be categorized into either vertical or horizontal relationships. Vertical relationships are the relationships which exist between superiorsubordinate, teacher-student, professorstudent, or parent-children. Horizontal relationships are established between an individual with his/her friends or other people who are equal. Such relationship pattern can be a source of perception differences. In vertical relationships, expectations can be perceived as injunction, so subjective norms will be developed because individuals have the motivation to comply with the injunction, whether to perform certain behaviors or not. On the other hand, in horizontal relationships, expectations are formed descriptively; as a consequence, there is willingness to imitate or identify the behaviors of others around them (Ramdhani, 2011).

\section{Perceived behavioral control}

Perceived behavioral control or behavioral control is individuals' perception of whether it is easy or difficult to perform certain behaviors (Ajzen, 2005). To explain perceived behavioral control, Ajzen distinguishes it from locus of control proposed by Rotter (1975; 1990). Locus of control is related to relatively stable individual beliefs in all situations. On the other hand, perceived behavioral control can change, depending on the situations and types of behaviors to perform. Locus of control is related to individuals' beliefs in their success in doing something, whether it depends on their own efforts or it depends on other factors outside themselves (Rotter, 1975).

Another concept that is quite close to perceived behavioral control is selfefficacy proposed by Bandura (in Ajzen, 2005). Self-efficacy is generally individuals' belief that they will succeed in mastering the skills required to complete certain tasks (Bandura, 1977; Pajares, 1996). The concept of perceived behavioral control proposed by Ajzen is affected by Bandura's study of self-efficacy by adding the importance of individual control over the resources that are required to perform certain behaviors (Ajzen, 2002).

In TPB, Ajzen (2005) mentions that perceived behavioral control is determined by individuals' beliefs in the availability of resources in the forms of tools, compatibility, competence, and opportunity (control belief strength) that support or inhibit the predicted behaviors and the extent of the roles of these resources (power of control factor) in performing such behaviors. The stronger the belief in the availability of resources and opportunities that individuals have in relation to certain behaviors, and the bigger the role of these resources, the stronger the individuals' perceived control over these behaviors. Individuals with a high perceived control will always be motivated and make efforts to succeed because they believe they could overcome any difficulties that they face with the help of any available resources and opportunities.

\section{Intention to use}

Intention to Use (ITU) is behavioral tendency of users to continue using a given technology (Davis, 1989). On the other hand, Wibowo (2006) states that it is the tendency to do something. Intention to use also reflects motivation and desire. In fact, individuals may have interests in something due to several factors such as internal factor, social factor and emotional factor. Internal factors include any needs related to the physical and psychological well-being of the individuals. Social factors are the ones driven by social motives such as to get recognition and appreciation from the environment where they belong to. Meanwhile emotional factors are the measures of individual intensity in paying attention to certain activities or objects. In marketing, generally there are two types of intentions that are very closely related to consumers, products, and companies, i.e. purchase intention and intention to use. These are two theories with many similarities.

\section{Impact attitude toward intention to invest}

Planned behavior theory proposed by Ajzen (1991) explain that attitudes to behavior are basic views about an individual's sense of agreement about what is being stimulated by his response, both positive or negative. A positive attitude views stock investment as profitable investment instruments. Conversely a negative attitude views that stock investment has a great risk. Attitude 
influenced by belief in beliefs strength and outcome evaluation.

H1: Attitude has a positive impact on intention to invest.

\section{Impact subjective norm toward intention to invest}

Subjective norms start from the influence of others because they are considered important (Subagyo, 2000). The environment will be very instrumental in taking someone's decision. People who are in the environment in which it surrounds has a positive influence on investment in the capital market will have the intention to investing in the capital market is greater than the people who are in an environment where people still don't agree with investment on the capital market.

H2: Subjective norm has a positive impact on intention to invest.

\section{Impact perceived behavior control toward intention to invest}

Ajzen in Subagyo (2000) revealed that perceived behavioral control is a person's belief that something can be controlled behavior or perception of ease or difficulty in undergoing a behavior influenced by something. A person's actions are influenced by a control. Each individual has control of the existence of a source power, skill, or possibility to show an action. If someone has all three controls, then he can have strong determination to show the behavior, in this case the ability to invest (Ismail \& Zain, 2008).

H3: perceived behavior control has positive impact on intention to invest.

\section{METHODS}

The data collection used questionnaires. The questionnaires were distributed online using Google Forms. The questionnaires were already validated by previous researchers and translated into Indonesian. Each of the research variables was measured using indicators. The respondents in this study were millennials. The survey was done by distributing the link of online survey one by one using social media such as Whatsapp, Line, and Instagram. The respondents were selected based on the characteristics of age, occupation, education, and gender.

The sampling method used to select the respondents in this study was nonprobability sampling. According to Cooper and Schlinder (2011), non-probability sampling is the probability of each element of population to be selected as an unknown sample. The non-probability sampling method used in this study was convenient sampling. Convenient sampling is a sampling technique based on the convenience of the researchers in selecting samples (Abdilah \& Jogiyanto, 2015). The characteristic of the respondents in this study was working millennials. In addition, it is important to determine the sample size in multiple regression analysis because it will affect the statistical significance and the generalization of the research results. The rule of thumb of the sample size in multiple regression analysis is at least 50 (Hair et al, 2010).

\section{Measurements}

A self-report questionnaire was administered that assess independent and dependent variable. The questionnaire contained 4 variables (attitude, subjective norm, perceived behavioral control, and intention to use).

Intention to invest. Investment interest is desire or strong desire for someone to learn everything related to investment to the stage of practicing it (investing). This variable is measured by using adapted instruments and developed from Kusniawati (2011). This variable is measured with a Likert scale 5 points.

Attitude. Choi Tung (2011) said that attitude toward the behavior is the degree to which a person has a favorable or unfavorable evaluation of a behavior. It depends on the person's assessment of the expected outcomes of the behavior. This variable is measured by using adapted instruments and developed from Kusniawati (2011). This variable is measured with a Likert scale 5 points.

Subjective norm. Subjective norms refer to the belief that an important person or group of people will approve and support a particular behaviour. Subjective norms are determined by the perceived social pressure from others for an individual to behave in a certain manner and their motivation to 
comply with those people's views (Marija Ham et al., 2015).

Perceived behavioral control. Perceived behavioral control is similar to self-efficacy both constructs refer to the person's belief that the behavior in question is under his or her control - but, operationally, perceived behavioral control is often assessed by the ease or difficulty of the behavior (Ajzen, 1988).

\section{Data analysis}

This research using multiple regression analysis. Regression tests are used when the researcher wants to determine the strength of the relationship (asymmetric) between the dependent variable and the independent variable (Gudono, 2012). Regression analysis is not only used to solve simple problems but also complex problems (Hair et al, 2010). Therefore, the purpose of regression testing is to predict one dependent variable from one or more independent variables.

\section{RESULTS AND DISCUSSION}

\section{Results}

Validity was first tested using Confirmatory Factor Analysis (CFA) using varimax rotation. The requirements to perform testing using CFA are KMO (Keizer-Meyer-Olkin) value $>0.5$ and Barlett's test significance $<0.05$ (Hair et al, 2010). Once the requirements regarding $\mathrm{KMO}$ and Barlett's test were met, the testing was continued in two phases. In the first phase, any indicators with cross loading and loading $<0.4$ were excluded. In the second phase, the same procedure was repeated until there was no cross loading and loading $>0.4$. Based on the results of the rotation, several statements had to be excluded, thus not included in further testing. The validity test results are in the following:

Based on the results of the KMO and Bartlett's test, the KMO value was 0.897 > 0.5 with a significance of 0.000 . This means that the result met the requirement for the first phase. However, for the second phase, there were three variables excluded, i.e. variables $\mathrm{C} 1, \mathrm{C} 2$, and $\mathrm{C} 5$. Other indicators were categorized as valid because they had factor loading greater than 0.5 .

Reliability testing was carried out to test the internal consistency of the measurement items. The reliability testing was done using Cronbach's Alpha method by including the valid indicators based on the result of the validity testing. In fact, reliability coefficient approaching 1 reflects reliability with a high internal consistency. Cronbach's Alpha coefficient $=0.5$ reflects low reliability, but can still be used and included in the next analysis. Reliability between 0.6 and 0.7 are fair, and a value $>0.8$ reflects high reliability (Hair et al., 2010). Based on the reliability testing, all the variables met the reliability criteria.

The $F$ test is used to validate the regression model. The value of the $F$ test results is also shown in table 4.8. Based on the value of the $F$ test, the significance of the model 1,2,3 shows a $p$ value of less than 0.05 . If the statistical value of the $F$ test is significant at alpha $5 \%$, then the

Table 1.

Hypotheses Testing

\begin{tabular}{llll}
\hline Variables & Model 1 & Model 2 & Model 3 \\
\hline Control variables & & & \\
Gender & .954 & .459 & .198 \\
Age & .116 & .476 & .872 \\
Education & .118 & .285 & .457 \\
\hline Independent Variables & & & \\
Atittude & .000 & & \\
Subjective Norm & & .182 & .260 \\
Perceived Behaviour Control & & & .158 \\
R2 & .621 & .187 & .067 \\
(R2 & .519 & .030 & .602 \\
F & 6.134 & .864 & \\
\hline
\end{tabular}


independent variables in models (1), (2), (3) are simultaneously assessed as being able to predict changes in the intention to invest variable (investment interest).

Table 1 also shows the value of $R 2$ which is the coefficient of determination, where it shows how much the independent variables in the model are able to explain the independent variables. Among the 3 models the greatest determination coefficient is model $(1)(R 2=0.621)$, and the smallest coefficient of determination is the model (3) $(\mathrm{R} 2=0.158)$. This means that, the independent variables contained in model (1) can explain the intention to invest variance of $62.1 \%$, while the rest is explained by other variables outside the model.

The value $\Delta R 2$ shows the change in $R 2$ in the next regression model after obtaining the addition of other independent variables that are included in the next model. The largest value of $\Delta R 2$ is found in model (1) $(\Delta R 2=0.519)$. This means that, the inclusion of contributing attitude variables provides an additional explanation of $51.9 \%$ for the variance that occurs in the intention to invest variable.

Hypothesis 1 in multiple regression testing shows that attitude has no influence on one's intention to invest $(\beta=-0.044 ; \mathrm{t}=$ $0.703 ; p>0.05)$. Then hypothesis 1 is not supported. While hypothesis 2 in multiple regression testing shows that subjective norm has a positive and significant effect on one's intention to invest $(\beta=-0.157 ; t=-$ $2.548 ; p<0.05)$. This is in line with the statement of hypothesis 3: perceived behavior control has a positive effect on intention to invest. Based on the test results, the hypothesis 2 and hypothesis 3 are stated supported.

\section{Discussion}

Investment is one of the patterns of financial management and risk management patterns. If in the past investment was only attractive to people who were economically well established, investment is now also in demand by the millennial generation. This is supported by the modification of the investment model that has been accessible to the millennial generation through their smartphones.

The variety of types of investment and access to investment information that is increasingly easy to obtain triggers the emergence of new segments in the investment market in Indonesia. The emergence of these new segments becomes interesting when researchers link with the theory of planned behavior. Theory of planned behavior is one theory that explains the process of a person in deciding his interest in something.

Theory of planned behavior explains the process of interest using three main components, namely attitude, subjective norm, and perceived behavior control. Based on the results of an analysis of attitudes towards investment interests, it is stated that they are not supported. This is because the millennial generation realizes the importance of investment but has not been able to apply the investment process. The application process may be due to the limitations they have, such as the funds they have not been able to be used for investment but can only be used for savings. So even though the millennials already have confidence in the importance of investment, they do not yet have an interest in investing. This is contrary to research conducted by Partridge and Ho (2003) revealed that attitude influences one's intention to invest. Alleyne and Broome (2011), Adam and Shauki (2012), Ezama, et al. (2014), Mahastanti and Hariady (2014), Sondari and Rahmat (2015), and Cuong and Zhou (2014) also support that attitude toward behavior can influence one's intention to invest. Gopi and Ramayah (2007), Schmidt (2010), and Azreen and Elvia (2012) state that attitude has a positive influence on investment intentions, this explains that the higher the positive response or positive attitude of someone to invest, the stronger the intention of someone to invest.

The second component is subjective norm. Based on the results of the research interest to invest is caused by the views of people around such as parents, friends, spouses, teachers / lecturers and colleagues who ignite the interest in investing in the millennial generation. That is because the closest people are believed to be directing to good things so that it is more effective to get the millennials to invest. In addition, closeness to someone will also lead to adherence to follow advice such as parents, teachers / lecturers. This is in line with Research Partridge and Ho (2003), Adam and Shauki (2012), Cuong and Zhou (2014), Ezama et al. (2014), Mahastanti and hariady (2014) and Sondari and Rahmat (2015) also 
produce that subjective norms can influence one's intention to invest. Gopi and Ramayah (2007), Schmidt (2010), and Azreen and Elvia (2012) state that subjective norms have a positive influence on investment intentions. This condition explains that the more people around individuals who support to invest, the higher the individual's intention to invest.

The third component is perceived behavior control. Perceived behavior control is determined by a person's beliefs about capacity, competence, and opportunity (control belief strength) that supports or inhibits the behavior to be predicted and the magnitude of the role of these resources (power of control factor) in realizing that behavior. Therefore, the stronger the belief in individual opportunities, available funds, and the knowledge possessed by individuals related to certain behaviors and the greater the role of these resources, the stronger the perception of individual control over these behaviors. Individuals who have a high perception of control will continue to be motivated and try to succeed in investing because they are confident that with the available resources and opportunities, the difficulties they face can be overcome. This is in line with Partridge and Ho Research (2003), Adam and Shauki (2012), Cuong and Zhou (2014), Ezama, et al. (2014), and Mahastanti and Hariady (2014) state that behavioral control can affect one's intention to invest. Gopi and Ramayah (2007) and Schmidt (2010) state that perceived behavioral control has a positive impact on investment desire. These conditions explain that the small or the least perceived obstacles to investing, the stronger one's intention to invest.

\section{CONCLUSION}

Theory of planned behavior explains the process of interest using three main components, namely attitude, subjective norm, and perceived behavior control. based on the results of an analysis of attitudes towards investment interests, it is stated that they are not supported. So it can be suggested for the government and the Indonesian stock exchange to better socialize the benefits and advantages of investing in stock in the capital market. the second component is subjective norm. Based on the research results, the interest to invest is caused by the views of people around you such as parents, friends, spouses, teachers / lecturers and colleagues who ignite the interest in investing in the millennial generation, so they are declared supported. In addition, it is recommended for the government and the Indonesian stock exchange that capital market socialization be done to groups or associations because the younger generation tends to spend more time with friends and colleagues. The third component is perceived behavioral control of investment interest, which is supported. based on the research findings, it is advisable to use persuasion that emphasizes the involvement of those closest to potential investors. in addition, seminars organized by IDX and the government will greatly help increase investor knowledge, thereby increasing one's investment power control. As for suggestions for future research, researchers should examine other variables that can increase interest in millennial investment such as technology adoption, easy access, and others.

\section{REFERENCES}

Abdillah, W. \& Hartono,J. (2011). Partial Least Square. Andi Yogyakarta: Yogyakarta

Abd, A. M., Abd, S. M., Ismail, A., \& Zain, M. F. M. (2008). Utilization of value engineering to optimize concreting productivity. Journal of Applied Sciences, 8(19), 3479-3484.

Aiken LS and Ajzen, I. (1985). From intentions to actions: A theory of planned behavior. In Action control (pp. 11-39). Springer, Berlin, Heidelberg.

Ajzen, I. (1988). Attitudes. Personality and Behavior, 134.

Ajzen, I. (1991) The theory of planned behavior. Organizational Behavior and Human Decision Processes, 50: 179-211.

Ajzen, I. (2002) Perceived behavioral control, self-efficacy, locus of control, and the theory of planned behavior. Journal of Applied Social Psychology,321-20.

Ayuningtyas, F., Prihatiningsih, W., \& Laura, R. (2018). The Pattern of Online Purchase Behavior by Millennial Family. Malaysian Journal of Social Sciences and Humanities (MJSSH), 3(5), 10-16.

Cable DM and DeRue DS (2002) The Convergent And Discriminant Validity Of Subjective 
Fit Perceptions. Journal of Applied Psychology 87(5): 875-884.

Chatman, Jennifer (1989). Improving Interactional Organizational Research: A Model of Person-Organization Fit. Academy of Management Review, 1989, Vol. 14, No. 3, 333-349

Churchill, Gilbert. (2005). Dasar-dasar Riset Pemasaran. Edisi 4. Erlangga.Jakarta

Couper, Donald. R., \& Schlinder, Pamela. S.(2011). Business Research Method. New York: McGraw-Hill.

Davis, F. D. (1989). Perceived usefulness, perceived ease of use, and user acceptance of information technology. MIS quarterly, 319-340.

Ferdinand, Augusty. (2006). Metode Penelitian Manajemen. BP Undip.Semarang

Fishbein, M. leek Ajzen (1975). Belief, attitude, intention and behavior: An introduction to theory and research, 181-202

Ghozali, Imam. (2006). Aplikasi Analisi Multivariate dengan Program SPSS. BP Undip. Semarang

Gudono.(2014). Analisis Data Multivariat.BPFE.Yogyakarta

Hair, J. F., Black, W. C., Babin, B. J., \& Anderson, R. E. (2010). Multivariate data analysis (7th ed.). Upper Saddle River, NJ: Prentice Hall

Hackman, J. R., \& Oldham, G. R. (1976). Motivation Through The Design Of Work: Test Of A Theory. Organizational Behavior and Human Performance, 16, 250-279.

King, M. R., \& Nesbitt, R. (2019). The Technological Revolution in Financial Services: Introduction. The Technological Revolution in Financial Services. Toronto: University of Toronto Press, Forthcoming.

Kusniawati, K. (2011). Zakat Sebagai Kebijakan Fiskal dalam Ekonomi Islam (Doctoral dissertation, Universitas Islam Negeri Alauddin Makassar).

Kiyosaki, R. T., \& Lechter, S. L. (2001). Rich Dad's Guide to Investing: What the Rich Invest In, that the Poor and Middle Class Do Not!. Business Plus.

Ham, M., Jeger, M., \& Frajman Ivković, A. (2015). The role of subjective norms in forming the intention to purchase green food. Economic research-Ekonomska istraživanja, 28(1), 738-748.

Menzel, M. P., \& Fornahl, D. (2010). Cluster life cycles-dimensions and rationales of cluster evolution. Industrial and corporate change, 19(1), 205-238.

Neuman, W.L. (2006) Social Research Methods: Qualitative and Quantitative Approaches 6 Th Edition, Pearson International Edition, USA

Ramdhani,Neila. (2011). Penyusunan Alat Pengukur Berbasis Theory of Planned Behavior. Buletin Psikologi Vol 19, NO. 2, 2011: 55 -

Runnemark, E., Hedman, J., \& Xiao, X. (2015). Do consumers pay more using debit cards than cash?. Electronic Commerce Research and Applications, 14(5), 285291.

Rotter, J. B. (1990). Internal versus external control of reinforcement: A case history of a variable. American psychologist, 45(4), 489.

Triwijayati, A., \& Koesworo, Y. (2006). Studi sikap dan niat konsumsi jamu pahitan di Surabaya. Jurnal Widya Manajemen \& Akuntansi, 6(1).

Tung, L. C. (2011). The impact of entrepreneurship education on entrepreneurial intention of engineering students. City University of Hongkong: Run Run Shaw Library.

West SG (1991) Multiple Regression: Testing and Interpreting Interactions. Newbury Park, CA: SAGE 